\title{
Turf Response to Urease Inhibitors and Cationic Materials Applied in Combination with Urea
}

\author{
Young K. Joo \\ Yonsei University, Institute of Agricultural Development, Seoul, 120-749, \\ Korea
}

Nick E. Christians

Iowa State University, Department of Horticulture, Ames, IA 50011

John M. Bremner ${ }^{3}$

Iowa State University, Department of Agronomy, Ames, IA 50011

Additional index words. urease inhibitors, phenylphosphorodiamidate, N-(n-butyl) thiophosphoric triamide, ammonium thiosulfate, ammonia volatilization, Poa pratensis

Abstract. We evaluated the response of Kentucky bluegrass (Pea pratensis L.) turf to urea amended with the urease inhibitors PPD, NBPT, and ATS and with the cations $\mathrm{K}^{+}(\mathrm{KCl})$ and $\mathrm{Mg}^{+2}\left(\mathrm{MgCl}_{2}\right)$. Treatments for the 2-year field experiment included liquid urea applied monthly in June to Sept. 1985 and 1986 at $49 \mathrm{~kg}$ N/ha with PPD (1\%, $2 \%, 3 \%$ by weight of applied N), NBPT $(0.5 \%, 1 \%, 2 \%)$, ATS $(5 \%, 15 \%, 25 \%)$, K+ $(5 \%, 15 \%, 25 \%)$, and $\operatorname{Mg}^{+2}(5 \%, 15 \%, 25 \%)$. The NBPT was included only in the 1986 field study. The $\mathrm{Mg}^{+2}$ and $\mathrm{K}^{+}$reduced foliar burn and increased turf quality during mid- and late Summer 1985 at the $5 \%$ rate, but clipping yield was not affected by any treatment. In 1986, under milder climatic conditions, PPD and NBPT increased clipping yield by $13.2 \%$ and $15.2 \%$, respectively. At the $15 \%$ rate, ATS increased clipping yield by $15.1 \%$, but, on average, PPD and NBPT were much more effective. Chemical names used: phenylphosphorodiamidate (PPD), $N$-(n -butyl) thiophosphoric triamide (NBPT), and ammonium thiosulfate (ATS).

Urea is a major source of nitrogen $(\mathrm{N})$ fertilizer for the turf industry because of its low cost, relatively low salt index, and compatibility in tank-mixed solutions with many of the pesticides used on lawns. Because of its versatility, liquid fertilization is rapidly becoming a popular method of applying urea to turfgrasses. The disadvantages of liquid fertilization with urea include potential foliar burn and relatively short residual response. Many researchers have reported that surface application of urea, in solid or liquid forms,

Received for publication 22 Mar. 1990. Journal Paper no. J-13942 of the Iowa Agriculture and Home Economics Experiment Station, Ames. Project no. 2231. The cost of publishing this paper was defrayed in part by the payment of page charges. Under postal regulations, this paper therefore must be hereby marked advertisement solely to indicate this fact.

'Assistant Professor of Horticulture.

${ }^{2}$ Professor of Horticulture, to whom reprint requests should be addressed.

${ }^{3}$ Distinguished Professor of Agronomy. involves the risk of considerable $\mathrm{N}$ loss as gaseous $\mathrm{NH}_{3}$ to the atmosphere. Also, field studies have shown urea to be less efficient than other $\mathrm{N}$ sources when surface-applied on grass sod. Researchers have attributed this $\mathrm{N}$ loss to the high urease activity in the plantthatch complex (Gasser, 1964; Spangenberg et al., 1986; Tomlinson, 1970; Torello and Wehner, 1983; Volk, 1959; Wesely, 1983).

During the past 15 years, numerous compounds have been proposed or patented as soil urease inhibitors (Bremner and Douglas, 1971; Bremner and Mulvaney, 1978; Hauck, 1984; Martens and Bremner, 1984; Mulvaney and Bremner, 1981). Such compounds act by retarding urea hydrolysis and may minimize the problems encountered in the use of urea when they are applied in combination with it. Other research (Martens and Bremner, 1984) has indicated that PPD was more effective than other compounds tested. Subsequent work (Bremner and Chai, 1986, 1989) showed that NBPT is considerably more effective than PPD for retarding urea hy- 
Table 1. Analysis of variance for foliar burn rating, turf quality, and clipping yield as affected by chemical treatments and month applied in the 1985 and 1986 field tests.

\begin{tabular}{|c|c|c|c|c|c|c|c|c|}
\hline \multirow[b]{3}{*}{ Source of variance } & \multicolumn{4}{|c|}{1985} & \multicolumn{4}{|c|}{1986} \\
\hline & \multicolumn{4}{|c|}{ Mean squares } & \multicolumn{4}{|c|}{ Mean squares } \\
\hline & $\mathrm{df}$ & $\begin{array}{l}\text { Burn } \\
\text { rating }\end{array}$ & $\begin{array}{c}\text { Turf } \\
\text { quality }\end{array}$ & $\begin{array}{l}\text { Clipping } \\
\text { yield }\end{array}$ & $\mathrm{df}$ & $\begin{array}{l}\text { Burn } \\
\text { rating }\end{array}$ & $\begin{array}{c}\text { Turf } \\
\text { quality }\end{array}$ & $\begin{array}{c}\text { Clipping } \\
\text { yield }\end{array}$ \\
\hline Chemical treatments & 12 & $0.61^{* *}$ & $0.15^{* *}$ & 267.45 & 15 & $0.29^{*}$ & 0.01 & 511.21 \\
\hline Control vs. PPD & (1) & $0.81^{*}$ & $0.12^{*}$ & 117.97 & (1) & 0.26 & 0.01 & $1036.25 * *$ \\
\hline vs. NBPT & (1) & $\ldots-{ }^{2}$ & --- & --. & (1) & 0.22 & 0.03 & $1355.48^{* *}$ \\
\hline vs. ATS & (1) & 0.16 & 0.00 & 0.29 & (1) & 0.00 & 0.04 & $350.73^{*}$ \\
\hline vs. $\mathrm{K}^{+}$ & (1) & 0.22 & 0.09 & 40.75 & (1) & 0.05 & 0.06 & 98.40 \\
\hline vs. $\mathrm{Mg}+2$ & (1) & 0.26 & $0.14^{*}$ & 310.66 & (1) & $0.42^{*}$ & 0.07 & 0.28 \\
\hline Error A & 36 & 0.08 & 0.05 & 166.59 & 45 & 0.12 & 0.36 & 338.19 \\
\hline Month applied & 3 & $0.35^{*}$ & $1.22^{* *}$ & $34,274.56^{* *}$ & 3 & $6.94^{* *}$ & $5.10^{* *}$ & $9937.80^{* *}$ \\
\hline Chemical $\times$ month & 36 & 0.08 & $0.05^{*}$ & 39.52 & 45 & $0.12 * *$ & $0.02^{* *}$ & 44.18 \\
\hline Error B & 117 & 0.13 & 0.03 & 152.88 & 144 & 0.09 & 0.01 & 57.25 \\
\hline
\end{tabular}

${ }^{2}$ No data available in 1985 .

*** Significant at $P=0.05$ and 0.01 , respectively.

Table 2. Effect of chemical treatments on average clipping yield during 4 weeks following monthly fertilization of Kentucky bluegrass turf with liquid urea at $49 \mathrm{~kg} \mathrm{~N} / \mathrm{ha}$.

\begin{tabular}{|c|c|c|c|c|c|c|c|c|c|c|c|}
\hline \multirow{3}{*}{\multicolumn{2}{|c|}{ Chemical }} & \multicolumn{10}{|c|}{ Clipping yield ${ }^{\mathbf{z}}$} \\
\hline & & \multicolumn{5}{|c|}{1985} & \multicolumn{5}{|c|}{1986} \\
\hline & & June & July & August & September & Avg & June & July & August & September & Avg \\
\hline \multirow{4}{*}{$\begin{array}{l}\text { Contro } \\
\text { PPD }\end{array}$} & & 44 & 94 & 79 & 49 & 66 & 84 & 59 & 63 & 74 & 70 \\
\hline & 1 & 43 & 89 & 83 & 41 & 64 & 100 & 72 & 69 & 72 & 78 \\
\hline & 2 & 49 & 94 & 80 & 43 & 66 & 110 & 80 & 71 & 81 & 85 \\
\hline & 3 & 38 & 82 & 78 & 36 & 59 & 95 & 63 & 64 & 76 & 74 \\
\hline \multirow[t]{3}{*}{ NBPT } & 0.5 & $\ldots-x^{x}$ & ... & $\ldots$ & -.. & -- & 100 & 69 & 68 & 84 & 80 \\
\hline & 1 & --- & --- & -- & $-\cdots$ & -- & 101 & 70 & 66 & 78 & 79 \\
\hline & 2 & .... & -..- & --.- & -..- & -.. & 102 & 75 & 73 & 82 & 83 \\
\hline \multirow[t]{3}{*}{ ATS } & 5 & 32 & 89 & 82 & 45 & 62 & 88 & 69 & 67 & 75 & 75 \\
\hline & 15 & 46 & 98 & 85 & 45 & 68 & 99 & 72 & 70 & 81 & 81 \\
\hline & 25 & 47 & 92 & 88 & 45 & 67 & 92 & 63 & 61 & 68 & 71 \\
\hline \multirow[t]{3}{*}{$\mathrm{K}^{+}$} & 5 & 46 & 91 & 86 & 47 & 67 & 81 & 61 & 63 & 69 & 69 \\
\hline & 15 & 47 & 101 & 87 & 49 & 71 & 89 & 65 & 62 & 70 & 71 \\
\hline & 25 & 43 & 90 & 81 & 48 & 66 & 92 & 71 & 72 & 79 & 79 \\
\hline \multirow[t]{3}{*}{$\mathrm{Mg}^{+2}$} & 5 & 49 & 105 & 92 & 53 & 75 & 89 & 65 & 68 & 77 & 75 \\
\hline & 15 & 47 & 97 & 88 & 51 & 71 & 86 & 63 & 66 & 71 & 71 \\
\hline & 25 & 43 & 101 & 82 & 47 & 68 & 83 & 56 & 57 & 64 & 65 \\
\hline \multicolumn{2}{|l|}{$\mathrm{SE}^{\mathrm{w}}$} & 6.3 & 6.3 & 6.3 & 6.3 & 3.2 & 5.7 & 5.7 & 5.7 & 5.7 & 4.6 \\
\hline
\end{tabular}

${ }^{2}$ Based on fresh weight $\left(\mathrm{g} / 1.5 \mathrm{~m}^{2}\right)$.

'Based on weight of applied $\mathrm{N}$.

${ }^{\times}$No data available in 1985.

"SE are the standard errors of the means within columns.

drolysis in soil and merits serious consideration as a fertilizer amendment for retarding hydrolysis of urea fertilizer by soil urease. Moreover, ATS, which has been most commonly used as a $\mathrm{N}$ and sulfur fertilizer, has been reported by Goos (1985) to have some urease-inhibiting characteristics in soil.

Another approach for reducing $\mathrm{NH}_{3}$ loss from surface-applied urea, by which $\mathrm{Ca}^{+2}$, $\mathrm{NH}_{4}^{+}, \mathrm{K}^{+}$, and $\mathrm{Mg}^{+2}$ were shown to reduce $\mathrm{NH}_{3}$ volatilization, was advanced by Fenn and Hossner (1985). Rappaport and Axley (1984) have also shown that $\mathrm{KCl}$ can improve urea-N efficiency by reducing $\mathrm{NH}_{3}$ volatilization.

In other field tests, $\mathrm{PPD}, \mathrm{Mg}^{+2}$, and NBPT were observed to increase the efficiency of surface-applied urea on turfgrass areas (Joo and Christians, 1984, 1986; Joo et al., 1987). The objectives of this study were to evaluate the effects of urea amended with urease inhibitors PPD, NBPT, and ATS and the cations $\mathrm{K}^{+}$(from $\mathrm{KCl}$ ) and $\mathrm{Mg}^{+2}$ (from $\mathrm{MgCl}_{2}$ ) on foliar bum, turf quality, and clipping yield of Kentucky bluegrass turf.
$\mathrm{CO}_{2}$ backpack sprayer operated in four directions to obtain uniform application. Three days after each application, foliar burn of the turfgrass foliage was estimated visually on a scale of $9=$ no visual burn and $1=$ dead turf. Visual quality, based primarily on color, uniformity, and density, was rated weekly on a scale of $9=$ best and $1=$ poorest. Fresh weights of clippings were determined weekly for 5 weeks after each treatment at a $5-\mathrm{cm}$ mowing height from two strips measuring $0.5 \times 1.5 \mathrm{~m}$ each and extending through the center of the plots. After data were collected, all plot areas were mowed uniformly at a height of $5 \mathrm{~cm}$, and clippings were removed.

Differences among treatments were small in 1985 due to a very dry period in early summer that restricted growth. The effects of the treatments on foliar burn and turf quality varied with chemical rates and time of application (Table 1). Plots treated with $\mathrm{K}^{+}$ and $\mathrm{Mg}^{+2}$ at the $5 \%$ rate had small but consistent rductions in foliar burn and increases in turf quality during mid- and late summer relative to the control (data not shown).

There was less heat stress on the grass in the 1986 study. Clipping yield increased on plots treated with PPD and NBPT as compared with the control ( $\mathrm{N}$ alone), but there were no significant differences among the rates of PPD and NBPT. Plots treated with the $15 \%$ rate of ATS had a clipping yield increase of $15 \%$, but ATS was less effective than PPD and NBPT overall (Table 2). The effects of PPD and NBPT on the relative yield increase, as compared with the control, were greatest in June 1986 (Table 2). This difference likely was due to increased $\mathrm{NH}_{3}$

the control during this high-temperature period. The average increases over 4 months were $12.0 \%, 21.79 \%$, and $6.0 \%$ on plots treated with PPD at $1 \%, 2 \%$, and $3 \%$, respectively (Table 2). The average increase of clipping yield over 4 months was $14.7 \%$, $12.4 \%$, and $18.4 \%$ with the $0.5 \%, 1 \%$, and $2 \%$ NBPT treatments, respectively, as compared with the control (Table 2).

The studies reported here did not measure the quantity of $\mathrm{NH}_{3}$ volatilized directly however, the positive effects of the urease inhibitors PPD and NBPT on growth response indicate that a reduction of $\mathrm{N}$ loss and an increase in $\mathrm{N}$-use efficiency are possible when these materials are combined with liquid urea applications. These results, combined with other studies that have shown decreased $\mathrm{NH}_{3}$ volatilization when these materials are used (Joo and Christians, 1984, 1986; Joo et al., 1987, 1989), indicate that PPD and NBPT have a potential value for increasing $\mathrm{N}$-use efficiency of urea- $\mathrm{N}$ applied as a liquid fertilizer to turf. Further studies should be conducted to determine if these materials are effective at even lower rates than were used in this study.

\section{Literature Cited}

were applied monthly from June through September in both years. Each plot measured $2.32 \mathrm{~m}^{2}$, and each treatment was applied in the equivalent of 500 liters $\mathrm{H}_{2} \mathrm{O}$ /ha with a
Bremner, J.M. and H.S. Chai. 1986. Evaluation of N-butyl phosphorothioic triamide fore retar- 
dation of urea hydrolysis in soil. Commun. Soil Sci. Plant Anal. 17:337-351.

Bremner, J.M. and H.S. Chai. 1989. Effects of phosphoroamides on ammonia volatilization and nitrite accumulation in soils treated with urea. Biol. Fert. Soils 8:227-230.

Bremner, J.M. and L.A. Douglas. 1971. Inhibition of urease activity in soils. Soil Biol. Biochem. 3:297-307.

Bremner, J.M. and R.L. Mulvaney. 1978. Urease activity in soils, p. 149-196. In: R.G. Burns (ed.). Soil enzymes. Academic, London.

Fenn, L.B. and L.R. Hossner. 1985. Ammonia volatilization from ammonium or ammoniumforming nitrogen fertilizers. Adv. Soil Sci. 1:123-169.

Gasser, J.K.R. 1964. Urea as fertilizer. Soils Fert. 27:175-180.

Goos, R.J. 1985. Identification of ammonium thiosulfate as a vitrification and urease inhibitor. Soil Sci. Soc. Amer. J. 49:232-235.

Hauck, R.D. 1984. Technological approaches to improving the efficiency of nitrogen fertilizer use by crop plants, p. 551-560. In: R.D. Hauck (ed.). Nitrogen in crop production. Amer. Soc.
Agron., Madison, Wis.

Joo, Y.K. and N.E. Christians. 1984. The reduction of ammonia volatilization from turfgrass areas treated with surface-applied urea Iowa Turfgrass Res. Rpt. Iowa Coop. Ext Serv. Bul. FG-450:42-45.

Joo, Y.K. and N.E. Christians. 1986. The response of Kentucky bluegrass turf to PPD and $\mathrm{Mg}^{++}$applied combination with urea. J. Fert Issues 3:30-33.

Joo, Y. K., N.E. Christians, and J.M. Bremner 1987. Effect of $N(n$ - butyl) thiophosphoric triamide (NBPT) on growth response and ammonia volatilization following fertilization of Kentucky bluegrass (Pea pratensis L.) with urea. J. Fert. Issues 3:98-102.

Joo, Y. K., N.E. Christians, and J.M. Bremner. 1989. Effectiveness of urease inhibitors and cationic materials for reduction of ammonia volatilization from turfgrasses treated with urea p. 209-211. In: H. Takatoh (ed.). Proc. 6th Intl. Turfgrass Res. Conf., Tokyo, 31 July-5 Aug. 1989

Martens, D.A. and J.M. Bremner. 1984. Effectiveness of phosphoroamides for retardation of urea hydrolysis in soils. Soil Sci. Soc. Amer. J. 48:302-305.

Mulvaney, R.L. and J.M. Bremner. 1981. Control of urea transformations in soils, p. 153196. In: E.A. Paul and J.M. Ladd (eds.). Soil biochemistry. vol. 5. Marcel Dekker, New York.

Rappaport, B.D. and J.H. Axley. 1984. Potassium chloride for improved urea fertilizer efficiency. Soil Sci. Soc. Amer. J. 48:399-401.

Spangenberg, B. G., T.W. Fermanian, and D.J. Wehner. 1986. Evaluation of liquid-applied nitrogen fertilizers on Kentucky bluegrass turf. Agron. J. 78:1002-1006.

Tomlinson, T.E. 1970. Urea: Agronomic applications. Proc. Fert. Soc. 113:1-76.

Torello, W.A. and D.J. Wehner. 1983. Urease activity in a Kentucky bluegrass turf. Agron. J. 75:654-656.

Volk, G.M. 1959. Volatile loss of ammonia following surface application of urea to turf or bare soils. Agron. J. 51:746-749.

Wesely, R.W. 1983. Turfgrass response to foliar applied nitrogen. PhD Diss., Univ. of Nebraska, Lincohr. 